\title{
THE BACKGROUND AND NEW PERSPECTIVES AND AGRICULTURAL ASPECTS CONCERNING FOOD ALLERGY AND FRUIT HYPERSENSITIVITY
}

\author{
Running head: Food allergy
}

Magdalena Jasińska-Stroschein*, Piotr Szcześniak, Jacek Owczarek and Daria Orszulak-Michalak

Department of Biopharmacy, Medical University of Lodz Muszyńskiego 1, 90-151 Łódź, POLAND

*Corresponding author: e-mail: magdalena.jasinska-stroschein@umed.lodz.pl

(Received September 30, 2011/Accepted November 30, 2011)

\section{A B S T R A C T}

In this review, some features of fruit allergenicity including the pathophysiology, cross allergy reactions, most common allergens and novel pathways of reducing hypersensitivity reactions as far as agricultural aspects are concerned, were described.

Key words: food, allergy, fruits

\section{INTRODUCTION}

Allergy has been described as the epidemic of the 21 st century, affecting up to $40 \%$ of the general population in developed countries (ISAAC, 1998). The prevalence of allergic diseases like rhinitis and asthma has increased dramatically over the past few decades. Some studies have shown similar trends for food allergy (Grundy et al., 2002; Zuberbier et al., 2004), but there are fewer food allergy studies. As some authors indicate, there is limited availability of convincing evidence concerning food allergies that have not yet been studied longitudinally in as much detail as inhalant allergies (HoffmannSommergruber, 2005).

The term food allergy is used to describe an adverse immune response to foods (Johansson et al., 2004). Food allergy might vary by age, local diet, and many other factors. Conditions that may increase the risk of developing a food allergy include an increased permeability of the intestines to macromolecules in e.g. viral gastroenteritis, premature birth, or cystic fibrosis. 
Adverse reactions to food - classification

According to the European Academy of Allergy and Clinical Immunology (EAACI), adverse reactions to food involve toxic and non-toxic reactions which in turn are immune-mediated (food allergies) being IgE-mediated (e.g., typical food allergies, immediate allergic reactions, delayed allergic reactions and exercise induced ones) and non-IgE-mediated (e.g., Celiac disease). Non-immunemediated reactions include: enzymatic, pharmacological and undefined ones (Fig. 1).

The immunopathophysiology of gastrointestinal food allergy disorders results mainly from IgE hypersensitization. Hypersensitivity of the IgE-mediated type is attributed to the generation of $\mathrm{TH} 2$ cells that produce several interleukins: IL-4, IL-5, and IL-13 (Blázquez and Berin, 2008). Immediate hypersensitivities might occur within a few minutes to several hours after food consumption. Exercise-induced food allergies occur when the specific food is ingested just before or after exercise, although many cases of such allergies are not related to foods (Kidd et al., 1983; Sheffer and Austen, 1984). Delayed hypersensitivities are cell-mediated ones that involve the response of sensitized cells, usually lymphocytes, to the specific foreign substance that triggers the reaction. The main result is tissue inflammation, often restricted to certain sites in the body. Symptoms appear from 6 to $24 \mathrm{~h}$ after consumption of the offending food.
Non-immunological food reactions or food intolerances, in contrast to true food allergies, involve metabolic food disorders which are genetically determined metabolic deficiencies e.g., lactose intolerance. Food idiosyncrasies are adverse reactions to food that occur through unknown mechanisms. An allergy-like food intoxication is not an individualistic adverse reaction as everyone in the population is probably susceptible. However, such illnesses are often misdiagnosed as food allergy.

The immunological food allergies are defined as an abnormal immunological reaction in which the body's immune system overreacts to ordinarily harmless substances in foods. Approximately 5\% of infants and $1 \%$ of adults have food allergies (Bock et al., 1990). Allergic reactions are based, in turn, on four different immunological mechanisms (Type I, II, III, IV) (classification by Coombs and Gell) that describe food allergies as well as allergic reactions to pollens, mould spores, animal danders, insect venoms, and drugs. The most important reaction of food allergy is the type I mechanism "immediate hypersensitivity," that involves the formation of IgE. Food allergies also may involve other types of immunological mechanisms; however the IgE-mediated mechanism has been, by far, the best documented and understood.

The nature and severity of food allergic reactions may be various, resulting from the amount of the offending food ingested and the length 


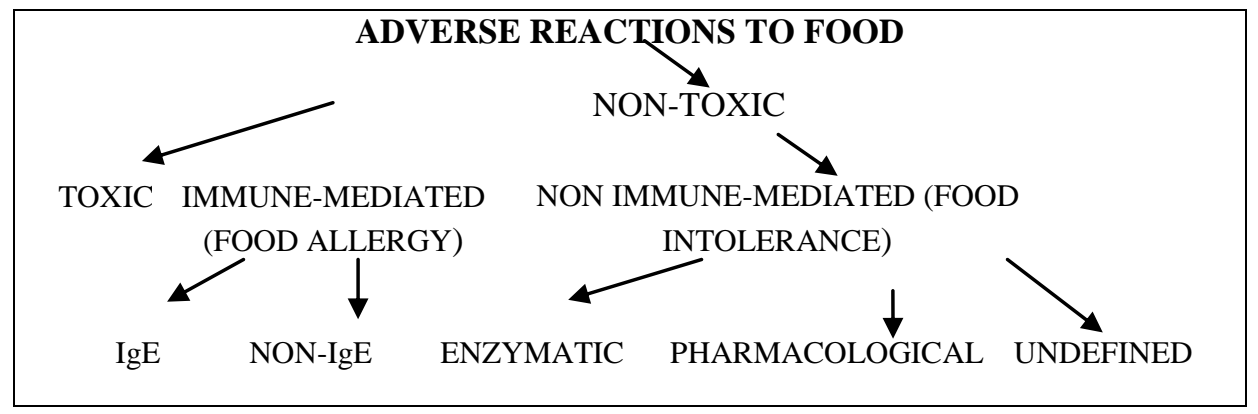

Figure 1. The classification of Adverse Reactions to Food (European Academy of Allergy and Clinical Immunology - EAACI)

of time since the last exposure. $\mathrm{Nu}$ merous symptoms ranging from mild to life threatening may be present. Systemic anaphylaxis is the most severe manifestation. Other symptoms that may occur include tongue swelling and itching, palatal itching, throat itching and tightness, nausea, abdominal pain, vomiting, diarrhea, dyspnea, wheezing, cyanosis, chest pain, urticaria, or severe angioedema (Hodge et al., 2009).

\section{The most common allergens asso- ciated with food allergies}

The most common food groups that are thought to be responsible for at least $90 \%$ of all food allergies are: cow's milk, crustacea (shrimp, crab, lobster), eggs, fish, peanuts, soybeans, tree nuts (almonds, walnuts) or wheat (Taylor et al., 1989). Some commonly allergenic foods, including cow's milk, eggs, and peanuts, contain multiple "major" and "minor" allergens.

Major allergens are defined as allergens that bind to serum IgE antibodies from more than $50 \%$ of patients with that specific food allergy.
For example, cow's milk contains several major allergens: casein, $\beta$ lactoglobulin, and $\alpha$-lactalbumin, white egg - ovomucoid (Gal d 1), ovalbumin (Gal d 2), and conalbumin (Gal d 3), shrimp - tropomyosin (Pen a 1, Pen I 1, Met e 1), peanut - concanavalin (Ara h 1, Ara h 2, Ara h 3), soybeans - oleosin, Brazil nut Ber e 1 (seed storage protein) and mustard - Sin a 1, Bra j 1 (Hauser et al., 2008). In contrast, minor allergens might include several other proteins that affect only a small percentage of allergic individuals.

The official allergen list of the International Union of Immunological Societies (IUIS) Allergen Nomenclature Subcommittee includes 130 plant-derived food allergens (faostat.fao.org). Most plant-derived food allergens, including fruit ones, can be integrated into only a few protein families and superfamilies on the basis of sequence homology, which is related to conserved threedimensional structures and possible function (Breiteneder and Radauer, 2004) (Tab. 1). 


\section{Jasińska-Stroschein et al.}

Table 1. Selected allergens of fruits and vegetables, included in the Official Allergen List (Hauser et al., 2008); according to: www.meduniwien.ac.at/allergens/allfam and www.allergome.org

\begin{tabular}{|c|c|c|}
\hline Protein family & Allergen source & Allergen \\
\hline nsLTP & $\begin{array}{l}\text { strawberry (Fragaria ananassa) } \\
\text { apple (Malus domestica) } \\
\text { apricot (Prunus armeniaca) } \\
\text { cherry (Prunus avium) } \\
\text { plum (Prunus domestica) } \\
\text { peach (Prunus persica) } \\
\text { pear (Pyrus communis) } \\
\text { raspberry (Rubus idaeus) } \\
\text { grape (Vitis vinifera) } \\
\text { lemon (Citrus limon) } \\
\text { tangerine (Citrus reticulata) } \\
\text { orange (Citrus sinensis) }\end{array}$ & $\begin{array}{l}\text { Fra a } 3 \\
\text { Mal d } 3 \\
\text { Pru ar } 3 \\
\text { Pru a } 3 \\
\text { Pru d } 3 \\
\text { Pru p } 3 \\
\text { Pyr c } 3 \\
\text { Rub i } 3 \\
\text { Vit } v 1 \\
\text { Cit } 13 \\
\text { Cit } r 3 \\
\text { Cit } \text { s } 3\end{array}$ \\
\hline Germins & orange (Citrus sinensis) & Cit $s 1$ \\
\hline PR-3 & avocado (Persea americana) & Pers a 1 \\
\hline PR-5 (TLP) & $\begin{array}{l}\text { kiwi (Actinidia deliciosa) } \\
\text { apple (Malus domestica) } \\
\text { cherry (Prunus avium) }\end{array}$ & $\begin{array}{l}\text { Act d } 2 \\
\text { Mald } 2 \\
\text { Pru av } 2\end{array}$ \\
\hline PR-10 (Bet v 1-related) & $\begin{array}{l}\text { gold kiwi (Actinidia chinensis) } \\
\text { strawberry (Fragaria ananassa) } \\
\text { apple (Malus domestica) } \\
\text { apricot (Prunus armeniaca) } \\
\text { cherry (Prunus avium) } \\
\text { peach (Prunus persica) } \\
\text { pear (Pyrus communis) } \\
\text { raspberry (Rubus idaeus) }\end{array}$ & $\begin{array}{l}\text { Act c } 6 \\
\text { Fra a } 1 \\
\text { Mal d } 1 \\
\text { Pru ar } 1 \\
\text { Pru av } 1 \\
\text { Pru p } 1 \\
\text { Pyr c } 1 \\
\text { Rub i } 1\end{array}$ \\
\hline Papain-like cysteine & $\begin{array}{l}\text { pineapple (Ananas comosus) } \\
\text { kiwi (Actinidia deliciosa) }\end{array}$ & $\begin{array}{l}\text { Ana c } 2 \\
\text { Act d } 1\end{array}$ \\
\hline Profilins & $\begin{array}{l}\text { pineapple (Ananas comosus) } \\
\text { strawberry (Fragaria ananassa) } \\
\text { apple (Malus domestica) } \\
\text { cherry (Prunus avium) } \\
\text { peach (Prunus persica) } \\
\text { pear (Pyrus communis) } \\
\text { orange (Citrus sinensis) } \\
\text { banana (Musa x paradisiaca) }\end{array}$ & $\begin{array}{c}\text { Ana c } 1 \\
\text { Fra a } 4 \\
\text { Mal d } 4 \\
\text { Pru a } 4 \\
\text { Pru } p 4 \\
\text { Pyr } c 4 \\
\text { Cit s } 2 \\
\text { Mus xp } 1\end{array}$ \\
\hline
\end{tabular}

As some authors state, the classification of allergens into protein families provides an overview on allergen distribution. The classification supplies insights into the clinical relevance in terms of cross-reactive allergy syndromes that may worsen the prognosis of an allergy. In addition, it might contribute to answering the question of allergenicity of dif- 
ferent proteins, help to define clinically relevant allergenic molecules, and explain the cross-reactivity phenomena between food allergen sources as well as food allergens and allergenic molecules of other origins (e.g. pollen). Most allergens are relatively small, hydrophilic, and stable proteins, apparently lacking bacterial homologues. The lack of such homologues, in turn, might reflect the dependency of allergenicity on transport over mucosal barriers and susceptibility to proteases. Interestingly, however, the question of what makes a protein an allergen still remains unanswered (Hauser et al., 2008).

\section{Fruit allergy}

Fruits are important components of a healthy diet. A diet without fruit can have a significantly negative impact. On the other hand, reactions of hypersensitivity to selected fruits (e.g., apple, strawberry, orange or kiwi) are still reported. Several allergens causing such allergic reactions have also been identified. For example, a study on 1139 patients from Northern Europe has shown that not only such popular allergenic tree nuts but also several fruits are a common cause of hypersensitivity. It was noted, that not only hazelnut $(n=46)$, walnut ( $n=32)$, chocolate $(n=31)$, but also fruits such as: apple $(n=45)$, orange $(n=36)$, kiwi $(n=32)$, and strawberry $(n=31)$ were the foods most often reported to elicit symptoms. Other fruits reported as the factors of food hypersensitivity were: peach, pear, nectarine, lemon, grapefruit, plum, cherry, grape, raspberry, banana, melon and avocado. Interestingly, the authors denoted that hypersensitivity to citrus fruits or strawberries was more common in children than in adults, whereas hypersensitivity to apples was less common as an offending food (Eriksson et al., 2004).

Several reports have investigated the risk of allergic reactions especially to small fruits. Small fruits from the Rosaceae family are an important nutritional source of vitamins and beneficial bioactive molecules (e.g., ascorbic acid, tocopherol, folic acid, phenolic compounds, anthocyanins, flavonoids, ellagic acid) (D'Amico et al., 2005). They also play a protective role against free radicals (Heo and Lee, 2004). Among the Rosaceae family, strawberries are currently one of the most popular berries grown. An estimated amount of 3.8 million metric tones of strawberries were consumed in 2007 (faostat.fao.org). Allergy to rosaceous fruits might be caused by four different protein families: $31 \mathrm{kDa}$ thaumatin-like proteins (TLPs, PR-5) with anti-fungal activity (Hsieh et al., 1995; Krebitz et al., 2003); $17.5 \mathrm{kDa}$ proteins belonging to pathogenesisrelated proteins (PR-10: Fra a 1; Rub I1) with high sequence homology to the major birch pollen allergen Bet $\mathrm{v} 1$ (Focke et al., 2003); 9 kDa nonspecific lipid transfer proteins (nsLTPs, PR-14) and a $14 \mathrm{kDa}$ prolinebinding protein known as profiling (Vanek-Krebitz et al., 1995).

Allergenic TLPs, have been reported in strawberries, but have not yet been reported in other small rosa- 
ceous fruits. In strawberries, raspberries and blackberries, PR-10s were found. The main cause of adverse reactions is considered to be Fra a 1; the PR-10 of strawberry (Karlsson et al., 2004). In raspberry, Rub i 1 was identified as an IgE-reactive, but as a low abundant PR-10 protein (Marzban et al., 2008a). Recently, profilins were described as clinically relevant allergens caused by Rosaceae fruits (Asero et al., 2008). An IgE-reactive profilin was reported as a putative allergen in strawberry, which might play a role in allergic symptoms after consumption (Zuidmeer et al., 2006). Profilins were also considered as a main cause for crosssensitization between pollen and fruits (Crespo et al., 2002). Besides PR-10 and PR-14, proteins of small fruits were shown to contain a more complex allergen pattern. In turn, a cyclophilin and a class III acidic chitinase were identified as the most IgE-reactive proteins in raspberries (Marzban et al., 2008b).

Investigations also demonstrated that the composition of IgE-reactive proteins in small fruit may differ principally from a well-studied allergen. Small fruits show a more complex $\operatorname{IgE}$ reactive protein pattern compared to apple or peach. Therefore, more clinical investigations are necessary to understand the significance and the impact of crossreactivity for new putative allergens.

Other fruits from the Rosaceae family including: peach, apricot, plum, almond, cherry (Prunoideae subfamily), apple, and pear (Pomoideae subfamily) have also been increasingly reported as causes of allergic reactions, particularly in adults with pollinosis (Cuesta-Herranz et al., 1998; Rodriguez et al., 2000). Patients allergic to such fruits frequently have positive skin tests or radioallergosorbent test.

In recent years, several allergens have been identified and sequenced in peach, apricot, plum, almond, cherry, apple or pear. The major allergens in pear are Pyr c 1, apricot - Pru ar 1, and sweet cherry - Pru av 1 . These are structural homologs to the birch pollen major allergen Bet $\mathrm{v} 1$, which belongs to class 10 of pathogenesis-related proteins (Scheurer et al., 1999; VanekKrebitz et al., 1995). Other major allergens are Pru av 2 (cherry) that have been identified as thaumatin-like proteins (Inschlag et al., 1998). More recently, a lipid transfer protein has been reported to be an important allergen in peach (Pru p 3), and apricot (Pru ar 3 ) (Pastorello et al., 1999a; SánchezMonge et al., 1999).

Apples are among the most common edible fruits and form an important source of vitamins and fibre in the diet of the European population. The yearly consumption in Europe is $20-25 \mathrm{~kg}$ per capita (a total of $>10$ million metric tons). It has been estimated that up to $2 \%$ of the northern and central European populations, including both children and adults, are allergic to apples (Fernández-Rivas et al., 2006). The reason for the allergy is the existence of four main classes of allergens, with different clinical relevance according to the geographical area, namely, Mal d 1, Mal d 2, Mal d 3, and Mal d 4. Allergic differences 
among apple cultivars are mainly related to differences in expression levels of Mal d 1 with its 18 different isoforms. Allergic reactions caused by Mal d 1, the major apple allergen, mainly affect northern and central European populations, and are often associated with birch pollinosis due to cross-reactivity with Bet $\mathrm{v} 1$ (Fritsch et al., 1998). The proteolysis sensitive allergen Mal d 1 does not survive most processing activities such as cooking or juice making. For this reason, it has been indicated that only consumption of fresh apples may lead to the development of allergy symptoms. The allergens, Mald 3 and Mal d 4 are, in turn, nonspecific lipid transfer protein causing class I food allergies (Pastorello et al., 1999b) mostly prevalent in the Mediterranean area (Ballmer-Weber, 2002). There is little known about Mal d 2-related allergy occurrence.

\section{Cross allergy reactions including fruits}

The issue of cross-contact of allergenic foods with other foods from the use of shared facilities and equipment, has come under growing attention. Such cross-contact is linked to incidents of allergic reactions in individuals that became ill from the consumption of products containing low levels of undeclared allergenic foods (Taylor et al., 1999). Crossreactivity to closely related foods seems to occur among some foodallergic patients.

Cross-reactions also are known to occur between some types of pol- lens and several fruits or vegetables. They might occur among ragweed pollen and melons (watermelon, cantaloupe, honeydew); mugwort pollen and celery or mugwort pollen and hazelnuts.

The most frequently described cross-reactive phenomenon is allergy to birch pollen and fruits. Approximately, $70-90 \%$ of birch pollen allergic individuals were described as also developing an intolerance to a number of rosaceous fruits. These people displayed predominantly mild allergic symptoms when eating plant foods such as apple, peach, tree nuts, celery or spices. Such reactions might be caused by particular proteins, demonstrating high similarity in their primary protein sequence with nearly identical tertiary structures. Several studies designed to assess the in vivo and in vitro crossreactivity between some fruits of the Rosaceae family, provided additional information on clinical crossreactivity.

Allergy to apple with sensitization to birch pollen has been quite frequently described. The major apple allergens with established links to birch pollen sensitization studied in the SAFE program were Mal d 1, Mal d 4 (Ebner et al., 1995; VanekKrebitz et al., 1995). Those apple allergens without clear links to pollen sensitization were Mal d 2, Mal d 3 (Hsieh et al., 1995; Krebitz et al., 2003). The major apple allergen Mal d 1 is homologous to the major birch pollen allergen Bet $\mathrm{v} 1$. It has been revealed that primary sensitization occurs via Bet $\mathrm{v} 1$, resulting in cross- 
reactivity of $\operatorname{IgE}$ to Mal d 1 . This allergen is exclusively linked to mild and local allergic symptoms together referred to as the oral allergy syndrome. The second apple allergen Mal d 2 is a thaumatin-like protein (TLP), representative of another family of pathogenesis-related proteins (PR5) (Hsieh et al., 1995; Krebitz et al., 2003). A thaumatin-like protein has been identified as an allergen in a limited number of other foods like kiwi, cherry, grape, and bell pepper (Gavrović-Jankulović et al., 2002; Inschlag et al., 1998; Leitner et al., 1998; Pastorello et al., 2003).

In Southern Europe, where birch trees are virtually absent, allergies to apple and related Rosaceae fruits such as peach and plum are frequently severe and found in both pollen and non-pollen allergic patients (Scheurer et al., 1999). Pastorello et al. (1999a) evaluated the immunologic cross-reactivity of fruits in the Prunoideae subfamily (peach, cherry, apricot, and plum). In our study, peach was the most common cause of Rosaceae clinical allergy, alone or associated with other fruits, especially apple, apricot, and plum (Pastorello et al., 1999a).

These reactions might also occur among birch pollen and some vegetables (e.g., carrots, or potatoes). Other allergic cross-reactions involving fruits were the reactions between latex and fruit, particularly banana, chestnut, and avocado.

Moreover, Pérez-Ezquerra et al. (2007) reported cases of allergy to grass pollen with an oral allergy syndrome involving several fruits from 2 different families of the Rosidae subclass (currant and raspberry) with grass pollen allergens.

\section{Anaphylactoid reactions and fruits}

Anaphylactoid reactions are caused by substances that bring about the non-immunologic release of these same mediators from mast cells without the involvement of IgE. In anaphylactoid reactions, some substances in the implicated food are presumed to destabilize the mast cell membranes. This effect allows the spontaneous release of the histamine and other mediators. The evidence for the existence of anaphylactoid reactions is actually the lack of evidence for an IgE-mediated mechanism in a few types of food allergy, such as strawberry allergy. Strawberries are known to cause adverse reactions e.g., frequently urticaria in some individuals. Additionally, no evidence has been obtained for the existence of strawberry-specific IgE in the sera of strawberry-sensitive individuals. The symptoms of strawberry "allergy" are very similar to those occurring in IgE-mediated food allergy. The in vivo release of histamine and other mediators might be a possible mechanism.

\section{The agricultural aspects of fruit allergies in recent studies}

Recent fruit-related allergy studies involve identification of fruit allergens and the impact of their genes over-expression; the role of pathogenesis-related proteins (PR) or the influence of agricultural factors such as: shadowing, elevation, water 
stress or storage, on allergy risk (Botton et al., 2008; Schmitz-Eiberger and Matthes, 2001). Agricultural factors, in turn, might be linked to changes in the expression of allergen-related genes. For example, Botton et al. (2008) have elucidated that shadowing may have a significant effect on the transcription of major apple allergen - Mal d 1 genes with their upregulation mainly in fruit skin which is directly exposed to the light. Other factors possibly affecting gene expression are storage conditions and the significant, positive linkage revealed especially for apple Mal d 1 . As the authors observed, the earlier harvested fruit cultivars might have a higher allergenic potential (Botton et al., 2008). Moreover, the expression of some genes might decrease in the storage period under controlled atmosphere conditions (i.e. 2,5\% oxygen and $1 \%$ carbon dioxide at $3{ }^{\circ} \mathrm{C}$ ) (Sancho et al., 2006). Brenna et al. (2004) reported the case of dependence of allergen contents on fruit ripening for different peach (Prunus persica) cultivars. Some authors claim that hypersensitivity reactions might also differ, depending on the cultivar (Matthes et al., 2009).

The important issue is reducing allergenicity of plant-based food products through the silencing of several allergens. Complete avoidance of apple or other fruits due to their allergenicity, however, might result in important deficiencies of vitamins, minerals and fibres. The SAFE project ("Plant food allergies: field to table strategies for reducing their incidence in Europe") has aimed at designing strategies to reduce the allergic reactions to apple, which is known as the most important allergenic fruit. One of the outcomes was to identify the differences in allergenicity for selected allergens (Mal d 1 and Mal d 3), for further studies on the development of ahypoallergenic apple by RNA-interference. The authors stated that such experiments may offer safe immunotherapy for food allergy (HoffmannSommergruber et al., 2005). Some cases concern the risk of adverse reactions if the fruit is eaten with the peel. This may be linked to the distribution of individual allergens over fruit which is exposed to pesticides, and is picked, transported, stored or processed. This process can have an impact on the risk of allergenicity. The studies on fruit allergies might use the proteomic analyses, being the large-scale study of proteins, particularly their structures and functions. These analyses are confronted with a series of specific obstacles: general low protein content in plant tissues, allergen extraction from highly complex matrices and protein determination in the presence of interfering compounds. For example, Hjernø et al. (2006) have used proteomic screening for identifying the up- or down-regulated proteins contributing to strawberry allergy. They found that allergens might participate in the synthesis of fruit colour, e.g., their down-regulation may explain a better tolerance of white strawberries in contrast to red ones. The authors noted that only several proteins in the white strawberry proteome includ- 
ing: ascorbate peroxidase, methionine sulfoxide reductase, and proteasome subunits were up-regulated, and these proteins are associated with oxidative stress and protein degradation. They concluded that white strawberries experience stress under normal growth conditions and might have reduced levels of flavonoids, which are photoprotective screeners and antioxidants (Hjernø et al., 2006).

Considering fruit-related allergies, another issue is the growing interest in genetic engineering as a great potential tool for improving the safety of plant-based foods by eliminating allergenic components. Singh et al. (2008) discussed the possibilities of reducing allergenicity of plant-based food products through the silencing of several allergens, based on the reports about peanuts and tomatoes as well as soybeans or rice grains. Such studies have also been performed on fruits (Singh and Bhalla, 2008). For example, Gilissen et al. (2005) successfully reduced Mal d 1 expression by RNA interference. This translated into significantly reduced in vivo allergenicity. The authors concluded that their observations support the feasibility of the production by gene silencing of apples hypoallergenic for Mal d 1 (Gilissen et al., 2005).

Another issue, is the growing interest of organic cultivation. Organic plant products are considered those produced with natural goods and services, such as biodiversity, nutrient cycling, soil regeneration and natural enemies of pests. Organic products are produced without the use of pesticides and without the addition of readily soluble mineral fertilizers. Taking into consideration the possibilities of reducing fruit allergenic potential, the next question is whether switching to organic production might decrease the allergenicity risk, since there are potential changes of gene expression. For the most part, data on the influence of the cultivation method on selected apple allergens did not indicate any significant differences. However, based on gene expression studies, Matthes et al. (2009) showed that in most apple cultivars from integrated production, there were significantly higher allergen concentrations in comparison to apples cultivated according to organic production guidelines. The authors explained that observed changes might depend on pathogenesis-related proteins (PR). For example, synthesis of allergens in organic fruits may be induced by biotic stress factors such as fungi, viruses, and bacteria. Some authors claim that pesticide treatment might provoke a stronger response than any biotic factors, throwing light on the meaning of agronomical practices and environmental conditions. The linkage between selected environmental and agricultural factors and fruit allergenicity was summarized in Table 2.

Clear experimental evidence supporting this assumption is still being examined, and the evaluation of the nutritional potential of organic products requires further research. One of the tasks of the EkoTechProdukt Project is the assessment of the hypoallergenic potential of selected fruits (apple, strawberry, cherry). 
The background and new perspectives.....

Table 2. Environmental and agricultural factors affecting fruit allergenicity - a summary

\begin{tabular}{|l|l|l|}
\hline \multicolumn{1}{|c|}{$\begin{array}{c}\text { Factor and taken actions af- } \\
\text { fecting fruit allergenicity }\end{array}$} & \multicolumn{1}{|c|}{ Result } & \multicolumn{1}{|c|}{ Reference } \\
\hline Shadowing & $\begin{array}{l}\text { Possible up-regulation of } \\
\text { major apple allergen - } \\
\text { mal d 1 }\end{array}$ & Botton et al. (2008) \\
\hline Early harvest & $\begin{array}{l}\text { Possible higher allergenic } \\
\text { fruit potential }\end{array}$ & Botton et al. (2008). \\
\hline $\begin{array}{l}\text { Storage period under con- } \\
\text { trolled atmosphere conditions } \\
\text { (i.e. 2,5\% oxygen and 1\% } \\
\text { carbon dioxide at } 3{ }^{\circ} \text { c) }\end{array}$ & $\begin{array}{l}\text { Decreased expression of } \\
\text { some fruit allergen genes }\end{array}$ & Sancho et al. (2006) \\
\hline $\begin{array}{l}\text { Terms of cultivar production } \\
\text { i.e. influence of biotic stress } \\
\text { factors such as fungi, viruses, } \\
\text { and bacteria, dryness }\end{array}$ & $\begin{array}{l}\text { Changes of fruit aller- } \\
\text { genic potential }\end{array}$ & Matthes et al. (2009) \\
\hline Fruit cultivar & $\begin{array}{l}\text { Different fruit allergenic } \\
\text { potential }\end{array}$ & Matthes et al. (2009) \\
\hline $\begin{array}{l}\text { Producing “colourless" culti- } \\
\text { vars }\end{array}$ & $\begin{array}{l}\text { Down-regulation of fruit } \\
\text { allergens }\end{array}$ & Hjernø et al. (2006) \\
\hline $\begin{array}{l}\text { Selected allergy-linked gene } \\
\text { silencing }\end{array}$ & $\begin{array}{l}\text { Producing of hypoaller- } \\
\text { genic fruits }\end{array}$ & Gilissen et al. (2005) \\
\hline $\begin{array}{l}\text { Dietary habits (i.e. eating fruit } \\
\text { without the peel) }\end{array}$ & $\begin{array}{l}\text { Decrease risk of fruit } \\
\text { allergenic potential }\end{array}$ & $\begin{array}{l}\text { Hoffmann- } \\
\text { Sommergruber (2005) }\end{array}$ \\
\hline
\end{tabular}

Selected aspects of fruit-related allergy - the summary

Fruits are important component of a healthy diet. Eating fruit is strongly recommended to improve health. Avoiding fruit in the diet can have a significantly negative impact. Dietary studies show that the consumption of fruits and vegetables is at a higher level in southern European countries compared with other regions. The lowest levels are found in eastern European countries, followed by northern countries. Fruit and vegetable consumption is usually higher among women than men aged $30 \pm 32$ and among older people. Per- sons of low social status tend to have the lowest intake (Roos et al., 2001). In the EU, the mean fruit consumption per capita is about 90$95 \mathrm{~kg} /$ person, in Poland - 50-55 kg and the most popular are apples, citrus and small (berry) fruits. Fruits from the Rosaceae family are widely consumed and have been increasingly reported as causes of allergic reactions. The Rosaceae family includes fruits such as peach, cherry (Prunoideae subfamily), apple, pear (Pomoidaea subfamily), blackberry and strawberry (Rosoideae subfamily). Apples are highly recommended for a healthy diet because of their efficacy in re- 
ducing the risk of stroke, heart disease, and lung cancer (Botton et al., 2008). It is currently one of the most popular fruits being consumed and it is an important crop for European agriculture. A broad variety of cultivars with a variable degree of allergenicity are grown in various European countries. For example, it has been estimated that up to $2 \%$ of the northern and central European populations are allergic to apples. Strawberry has an unjustified reputation among the general population of being an allergenic fruit. As a questionnaire-based study showed, among young adults with a median age of 34 , the estimated prevalence of pollen allergy was 23\%. The prevalence of secondary food hypersensitivity (pollen related FHS) was high with kiwi, hazelnut, pineapple, apple and orange as the most common reported allergenic foods, and they are a major problem in young adults (Osterballe et al., 2009).

The allergenic activity of some food allergens is easily destroyed by heating or denaturing, such as the allergens in apples. Such destructive procedures may decrease the activity of Mal d 1- a major apple allergen. In other words, the initial gastronomic processing of fruits might reduce the risk of allergic incidents in persons being predisposed to such reactions. Other allergens, for instance in milk or fish, are resistant to denaturation which happens in cooking and digestion (Eshuis, 1997).

As indicated, sensitization to a certain fruit or vegetable might often be associated with sensitization to other foods belonging to the same or a closely related botanical family. For example; the most frequent clusters are apple and pear, potato, and carrot; melon, watermelon and tomato; peach, apricot, plum and cherry. Another cross-reactivity is based on inhalant allergens (aeroallergens) and food allergens. During adolescence, there is an ever increasing possibility of becoming allergic to food allergens that cross-react with inhalant allergens such as pollen and the allergens of house-dust mite and pets. That is why patients allergic to birch pollen are frequently sensitized to numerous fresh fruits (apple, kiwi, orange, peach, apricot, cherry), vegetables (carrot, potato, celery, fennel) and hazelnuts. Many mugwort-sensitive patients react to vegetables including: celery, fennel, carrot, parsley and spices (like anise, coriander). The above reaction is described as the Mugwort-CelerySpice syndrome. Similarly to another allergy-related symptom: angioedema, the signs of the described syndrome can be very severe. Other cross-reacting allergens between pollen and foods might be caused by ragweed pollen, melon, banana, watermelon and pumpkin or grass pollen and potato, peanut, buckwheat, wheat and tomato. In some cases, the diagnostics of fruit-related allergies can be difficult. One exception is the Oral Allergy Syndrome (OAS). Blood tests of patients with OAS for specific IgE antibodies, are nearly always positive. In adults suffering from pollen allergy, the prevalence of this syndrome has been estimated 
to be about $40 \%$, making it a very common condition. As indicated, approximately $50 \%$ of patients allergic to birch pollen and having a cross-reaction to apple, peach and hazelnut, suffer from OAS. Patients suffering from allergies to certain pollen, more often react with the Oral Allergy Syndrome (OAS) to certain fresh fruits and vegetables, like apple, peach, cherry, nuts, celery, carrot and tomato. In the OAS, the lips, cheeks, tongue or throat may swell or itch within 15 minutes of contact with a specific food. Usually these symptoms disappear very quickly.

Several positive aspects on the background of allergic reactions and fruit consumption have been reported over the last few years. Previous cross-sectional studies suggest that fruit and vegetable consumption reduces the risk of allergic disease in children. For example, Rosenlund et al. (2011) investigated the association between current fruit or vegetable intake and allergic disease in 2447 8-year-old Swedish children, to evaluate the potential effect of disease-related modification of consumption. An inverse relation was observed between total fruit consumption and rhinitis, whereas no association was observed for total vegetable intake. In analyses of individual foods, intake of apples/pears and carrots was inversely associated with rhinitis, asthma, and atopic sensitization. Fifty percent of children with rhinitis were sensitized against birch pollen, which may cross-react with apples and carrots. After exclusion of children who developed food- related allergic symptoms, most of the observed inverse associations were found to be untrue and became non-significant. Also, several studies have shown that asthma outcomes were negatively associated with citrus fruits, apples, pears, tomato, carrots or leafy vegetables. For example in study being undertaken to investigate whether dietary intake predicted the prevalence of adult asthma in 68 535 French women, the authors suggested that the intake of some vegetables may decrease the prevalence of adult asthma (Romieu et al., 2006). After adjusting for age, body mass index, menopausal status, smoking status, total caloric intake, physical activity, and use of dietary supplements, women who had a greater intake of tomatoes, carrots and leafy vegetables had a lower prevalence of asthma. Apples were marginally related to the prevalence of asthma and no other fruits or vegetables were significantly associated with asthma prevalence. Similarly, in a recent case-control study, Shaheen et al. (2001) reported that consumption of apples and red wine were negatively related to asthma, suggesting the beneficial effect of flavonoids. The authors indicated a number of reasons for exploring the effects of fruit and vegetables rather than individual nutrients. Nonetheless, the findings by Fogarty et al. (2009) demonstrated that the provision of daily fruit at school for $1 \mathrm{yr}$ might have no impact on the prevalence or severity of asthma symptoms in young children. 
Acknowledgements: This research is supported by a grant from the European Regional Development Fund through the Polish Innovation Economy Operational Program, contract N. UDA-POIG.01.03.01-10-109/08-00.

\section{REFERENCES}

Asero R., Monsalve R., Barber D. 2008. Profilin sensitization detected in the office by skin prick test: a study of prevalence and clinical relevance of profilin as a plant food allergen. CLIN. EXP. ALLERGY. 38: 1033-1037.

Ballmer-Weber B.K. 2002. Lipid transfer protein as a potential panallergen? ALLERGY. 57: 873-875.

Blázquez A.B., Berin M.C. 2008. Gastrointestinal dendritic cells promote $\mathrm{Th} 2$ skewing via OX40L. J. IMMUNOL. 180: 4441-4450.

Bock S.A., Atkins F.M. 1990. Patterns of food hypersensitivity during sixteen years of double-blind, placebocontrolled food challenges. J. PEDIATR. 117: 561-567.

Botton A., Lezzer P., Dorigoni A., Barcaccia G., Ruperti B., Ramina A. 2008. Genetic and environmental factors affecting allergen-related gene expression in apple fruit (Malus domestica L. Borkh). J. AGRIC. FOOD. CHEM. 56: 6707-6716.

Breiteneder H., Radauer C. 2004. A classification of plant food allergens. J. ALLERGY CLIN. IMMUNOL. 113: 821-830.

Brenna O.V., Pastorello E.A., Farioli L., Pravettoni V., Pompei C. 2004. Presence of allergenic proteins in different peach (Prunus persica) cultivars and dependence of their content on fruit ripening. J. AGRIC. FOOD. CHEM. 52: 7997-8000.

Crespo J.F., Rodríguez J., James J.M., Daroca P., Reaño M., Vives R. 2002.
Reactivity to potential cross-reactive foods in fruit-allergic patients: implications for prescribing food avoidance. ALLERGY. 57: 946-949.

Cuesta-Herranz J., Lázaro M., de las Heras M., Lluch M., Figueredo E., Umpierrez A., Hernandez J., Cuesta C. 1998. Peach allergy pattern: experience in 70 patients. ALLERGY. 53: 78-82.

D'Amico E, Perrotta G. 2005. Genomics of berry fruits antioxidant components. BIOFACTORS. 23: 179-187.

Ebner C., Hirschwehr R., Bauer L., Breiteneder H., Valenta R., Ebner H., Kraft D., Scheiner O. 1995. Identification of allergens in fruits and vegetables: IgE cross-reactivities with the important birch pollen allergens Bet $\mathrm{v} 1$ and Bet $\mathrm{v}$ 2 (birch profilin). J. ALLERGY CLIN. IMMUNOL. 95: 962-969.

Eshuis N.H. 1997. Adverse Reactions to Food. The Brochure on Adverse Reactions to Food, by European Academy of Allergy and Clinical Immunology (EAACI) http://www.efanet.org/activities/docum ents/AdverseReactionstoFood.pdf (08.2011).

Eriksson N.E., Möller C., Werner S., Magnusson J., Bengtsson U., Zolubas M. 2004. Self-reported food hypersensitivity in Sweden, Denmark, Estonia, Lithuania, and Russia. J. INVESTIG. ALLERGOL. CLIN. IMMUNOL. 14: 70-79.

Fernández-Rivas M., Bolhaar S., González-Mancebo E., Asero R., van Leeuwen A., Bohle B., Ma Y., Ebner C., Rigby N., Sancho A.,I., Miles S., Zuidmeer L., Knulst A., Breiteneder H., Mills C., Hoffmann-Sommergruber K., van Ree R. 2006. Apple allergy across Europe: how allergen sensitization profiles determine the clinical expression of allergies to plant foods. J. ALLERGY. CLIN. IMMUNOL. 118: 481-48. 
The background and new perspectives.....

Focke M., Hemmer W., Wöhrl S., Götz M., Jarisch R. 2003. Cross-reactivity between Ficus benjamina latex and fig fruit in patients with clinical fig allergy. CLIN. EXP. ALLERGY. 33: 971-977.

Fogarty A.W., Antoniak M., Venn A.J., Davies L., Goodwin A., Salfield N., Britton J.R., Lewis S.A. 2009. A natural experiment on the impact of fruit supplementation on asthma symptoms in children. EUR RESPIR J. 33: 481-485.

Fritsch R., Bohle B., Vollmann U., Wiedermann U., Jahn-Schmid B., Krebitz M., Breiteneder H., Kraft D., Ebner C. 1998. Bet v 1, the major birch pollen allergen, and Mal d 1, the major apple allergen, cross-react at the level of allergen-specific $\mathrm{T}$ helper cells. J. ALLERGY. CLIN. IMMUNOL. 102(4 Pt 1): 679-686.

Gavrović-Jankulović M., Ćirković T., Vucković O., Atanasković-Marković M., Petersen A., Gojgić G., Burazer L., Jankov R.M. 2002. Isolation and biochemical characterization of a thaumatin-like kiwi allergen. J. ALLERGY CLIN. IMMUNOL. 110: 805-810.

Gilissen L.J., Bolhaar S.T., Matos C.I., Rouwendal G.J., Boone M.J., Krens F.A., Zuidmeer L., Van Leeuwen A., Akkerdaas J., Hoffmann-Sommergruber K., Knulst A.C., Bosch D., Van de Weg W.E., Van Ree R. 2005. Silencing the major apple allergen Mal d 1 by using the RNA interference approach. J. ALLERGY CLIN. IMMUNOL. 115: 364-369.

Grundy J., Matthews S., Bateman B., Dean T., Arshad S.H. 2002. Rising prevalence of allergy to peanut in children: Data from 2 sequential cohorts. J. ALLERGY CLIN. IMMUNOL. 110: 784-789.

Hauser M., Egger M., Wallner M., Wopfner N., Schmidt G., Ferreira F. 2008. Molecular properties of plant food allergens: A current classification into protein families. OPEN IMMUNOL. J. 1: 1-12.

Heo H.J., Lee C.Y. 2004. Protective effects of quercetin and vitamin $\mathrm{C}$ against oxidative stress-induced neurodegeneration. J. AGRIC. FOOD CHEM. 52: 7514-7517.

Hjernø K., Alm R., Canbäck B., Matthiesen R., Trajkovski K., Björk L., Roepstorff P., Emanuelsson C. 2006. Downregulation of the strawberry Bet $\mathrm{v} 1$ homologous allergen in concert with the flavonoid biosynthesis pathway in colorless strawberry mutant. PROTEOMICS. 6: 1574-1587.

Hodge L., Swain A., Faulkner-Hogg K. 2009. Food allergy and intolerance. AUST FAM PHYSICIAN. 38: 705-7.

Hoffmann-Sommergruber K. 2005. SAFE consortium, The SAFE project: "plant food allergies: field to table strategies for reducing their incidence in Europe" an EC-funded study. ALLERGY. 60: 436-442.

Hsieh L.S., Moos M Jr, Lin Y. 1995. Characterization of apple 18 and $31 \mathrm{kD}$ allergens by microsequencing and evaluation of their content during storage and ripening. J. ALLERGY CLIN. IMMUNOL. 96: 960-970.

Inschlag C., Hoffmann-Sommergruber K., O'Riordain G., Ahorn H., Ebner C., Scheiner O., Breiteneder H. 1998. Biochemical characterization of Pru a 2, a $23-\mathrm{kD}$ thaumatin-like protein representing a potential major allergen in cherry (Prunus avium). INT. ARCH. ALLERGY IMMUNOL. 116: 22-28.

Johansson S.G., Bieber T., Dahl R., Friedmann P.S., Lanier B.Q., Lockey R.F., Motala C., Ortega Martell J.A., PlattsMills T.A., Ring J., Thien F., Van Cauwenberge P., Williams H.C. 2004. Revised nomenclature for allergy for global use: Report of the Nomenclature Review Committee of the World Allergy Organization, October 2003. J. 
ALLERGY CLIN. IMMUNOL. 13: 832-836.

Karlsson A.L., Alm R., Ekstrand B., Fjelkner-Modig S., Schiött A., Bengtsson U., Björk L., Hjernø K., Roepstorff P., Emanuelsson C.S. 2004. Bet v 1 homologues in strawberry identified as IgEbinding proteins and presumptive allergens. ALLERGY. 59: 1277-1284.

Kidd J.M., Cohen S.H., Sosman A.J., Fink J.N. 1983. Food-dependent exerciseinduced anaphylaxis. J. ALLERGY CLIN. IMMUNOL. 71: 407-411.

Krebitz M., Wagner B., Ferreira F., Peterbauer C., Campillo N., Witty M., Kolarich D., Steinkellner H., Scheiner O., Breiteneder H. 2003. Plant-based heterologous expression of Mal d 2, a thaumatin-like protein and allergen of apple (Malus domestica), and its characterization as an antifungal protein. $\mathrm{J}$. MOL. BIOL. 329: 721-730.

Leitner A., Jensen-Jarolim E., Grimm R., Wüthrich B., Ebner H., Scheiner O., Kraft D., Ebner C. 1998. Allergens in pepper and paprika. Immunologic investigation of the celery-birch-mugwortspice syndrome. ALLERGY. 53: 36-41.

Marzban G., Herndl A., Kolarich D., Maghuly F., Mansfeld A., Hemmer W., Katinger H., Laimer M. 2008. Identification of four IgE-reactive proteins in raspberry (Rubus ideaeus L.). MOL. NUTR. FOOD RES. 52: 1497-1506.

Marzban G., Maghuly F., Herndl A., Katinger H., Laimer M. 2008. Screening and identification of putative allergens in berry fruits of the Rosaceae family: technical challenges. BIOFACTORS. 34: 37-46.

Matthes A., Schmitz-Eiberger M. 2009. Apple (Malus domestica L. Borkh.) allergen Mal d 1: effect of cultivar, cultivation system, and storage conditions. J. AGRIC. FOOD. CHEM. 57: 1054810553.
Osterballe M., Mortz C.G., Hansen T.K., Andersen K.E., Bindslev-Jensen C. 2009. The prevalence of food hypersensitivity in young adults. PEDIATR ALLERGY IMMUNOL. 20: 686-692.

Pastorello E.A., Farioli L., Pravettoni V., Ortolani C., Fortunato D., Giuffrida M.G., Perono Garoffo L., Calamari A.M., Brenna O., Conti A. 2003. Identification of grape and wine allergens as an endochitinase 4, a lipid-transfer protein, and a thaumatin. J. ALLERGY CLIN. IMMUNOL. 111: 350-359.

Pastorello E.A., Farioli L., Pravettoni V., Ortolani C., Ispano M., Monza M., Baroglio C., Scibola E., Ansaloni R., Incorvaia C., Conti A. 1999. The major allergen of peach (Prunus persica) is a lipid transfer protein. J. ALLERGY CLIN. IMMUNOL. 103: 520-526.

Pastorello E.A., Pravettoni V., Farioli L., Ispano M., Fortunato D., Monza M., Giuffrida M.G., Rivolta F., Scibola E., Ansaloni R., Incorvaia C., Conti A., Ortolani C. 1999. Clinical role of a lipid transfer protein that acts as a new apple-specific allergen. J. ALLERGY. CLIN. IMMUNOL. 104: 1099-1106.

Pérez-Ezquerra P.R., de la Gaspar M.V., de Fernández M.B., Flores V.T., AlvarezSantullano A.V., de Ocáriz M.L. 2007. Currant allergy and the Rosaceae-grass pollen allergy syndrome: a case report. ANN. ALLERGY. ASTHMA. IMMUNOL. 98: 480-2.

Rodriguez J., Crespo J.F., Lopez-Rubio A., De La Cruz-Bertolo J., Ferrando-Vivas P., Vives R., Daroca P. 2000. Clinical cross-reactivity among foods of the Rosaceae family. J. ALLERGY CLIN. IMMUNOL. 106: 183-189.

Romieu I., Varraso R., Avenel V., Leynaert B., Kauffmann F., ClavelChapelon F. 2006. Fruit and vegetable intakes and asthma in the E3N study. THORAX. 61: 209-215. 
Roos G., Johansson L., Kasmel A., Klumbiené J., Prättälä R. 2001. Disparities in vegetable and fruit consumption: European cases from the north to the south. PUBLIC HEALTH NUTR. 4: 35-43.

Rosenlund H., Kull I., Pershagen G., Wolk A., Wickman M., Bergström A. 2011. Fruit and vegetable consumption in relation to allergy: disease-related modification of consumption? J ALLERGY CLIN IMMUNOL. 127: 1219-1225.

Sánchez-Monge R., Lombardero M., García-Sellés F.J., Barber D., Salcedo G. 1999. Lipid-transfer proteins are relevant allergens in fruit allergy. J. ALLERGY CLIN. IMMUNOL. 103: 514-519.

Sancho AI., Foxall R., Browne T., Dey R., Zuidmeer L., Marzban G., Waldron KW., van Ree R, HoffmannSommergruber K., Laimer M., Mills EN. 2006. Effect of postharvest storage on the expression of the apple allergen Mal d 1. J AGRIC FOOD CHEM. 54: 5917-5923.

Scheurer S., Son D.Y., Boehm M., Karamloo F., Franke S., Hoffman A. 1999. Cross-reactivity and epitope analysis of Pru a 1, the major cherry allergen. MOL. IMMUNOL. 36: 155-167.

Schmitz-Eiberger M., Matthes A. 2001. Effect of harvest maturity, duration of storage and shelf life of apples on the allergen Mal d 1, polyphenoloxidase activity and polyphenol content. FOOD CHEMISTRY. 127: 1459-1464.

Shaheen S.O., Sterne J.A., Thompson R.L., Songhurst C.E., Margetts B.M., Burney P.G. 2001. Dietary antioxidants and asthma in adults: population-based casecontrol study. Am. J. Respir. Crit. Care Med. 164: 1823-1828.

Sheffer A.L., Austen K.F. 1984. Exerciseinduced anaphylaxis. J. ALLERGY CLIN. IMMUNOL. 73: 699-703.
Singh M.B., Bhalla P.L. 2008. Genetic engineering for removing food allergens from plants. TRENDS PLANT. SCI. 13: 257-260.

Taylor S.L., Hefle S.L., Munoz-Furlong A. 1999. Food allergies and avoidance diets. NUTR. TODAY. 34: 15-22.

Taylor S.L., Nordlee J.A., Rupnow J.H. 1989. Food allergies and sensitivities. In: Taylor S.L., Scanlan R.A. (Eds.), ,Food Toxicology: A Perspective on the Relative Risks, Marcel Dekker, New York, 255.

Vanek-Krebitz M., HoffmannSommergruber K., Laimer da Camara Machado M., Susani M., Ebner C., Kraft D., Scheiner O., Breiteneder H. 1995. Cloning and sequencing of Mal d 1, the major allergen from apple (Malus domestica), and its immunological relationship to Bet $\mathrm{v} 1$, the major birch pollen allergen. BIOCHEM. BIOPHYS. RES. COMMUN. 214: 538-551.

Worldwide variation in prevalence of symptoms of asthma, allergic rhinoconjunctivitis, and atopic eczema: ISAAC. The International Study of Asthma and Allergies in Childhood (ISAAC) Steering Committee. 1998. LANCET. 351: 1225-1232.

Zuberbier T., Edenharter G., Worm M., Ehlers I., Reimann S., Hantke T., Roehr C.C., Bergmann K.E., Niggemann B. 2004. Prevalence of adverse reactions to food in Germany - a population study. ALLERGY. 59: 338-345.

Zuidmeer L., Salentijn E., Rivas M.F., Mancebo E.G., Asero R., Matos C.I., Pelgrom K.T., Gilissen L.J., van Ree R. 2006. The role of profilin and lipid transfer protein in strawberry allergy in the Mediterranean area. CLIN. EXP. ALLERGY. 36: 666-675.

Food and Agriculture Organization of the United Nations. http://faostat.fao.org/ (08.2011). 


\title{
REAKCJE NADWRAŻLIWOŚCI NA POKARM, ZE SZCZEGÓLNYM UWZGLĘDNIENIEM OWOCÓW - PODSTAWY I PERSPEKTYWY
}

\author{
Magdalena Jasińska-Stroschein, Piotr Szcześniak, \\ Jacek Owczarek i Daria Orszulak-Michalak
}

\author{
S T R E S Z C Z E N I E
}

W niniejszym artykule podjęto zagadnienia związane $\mathrm{z}$ alergiami pokarmowymi, w tym alergiami wywoływanymi przez owoce, ze szczególnym uwzględnieniem podłoża patofizjologicznego, występowania alergii krzyżowych, najczęstszych alergenów odpowiedzialnych za opisywane reakcje oraz kierunków działań podejmowanych w celu zmniejszenia potencjalnej alergenności owoców.

Slowa kluczowe: pokarm, alergie, owoce 